\title{
RALA wt Allele
}

National Cancer Institute

\section{Source}

National Cancer Institute. RALA wt Allele. NCI Thesaurus. Code C52542.

Human RALA wild-type allele is located within 7p15-p13 and is approximately $85 \mathrm{~kb}$ in length. This allele, which encodes Ras-related protein Ral-A, plays a role in the mediation of ligand-induced signal pathways. 